Article

\title{
Dynamic and Economic Investigation of a Solar Thermal-Driven Two-Bed Adsorption Chiller under Perth Climatic Conditions
}

\author{
Ali Alahmer ${ }^{1,2}$, Xiaolin Wang ${ }^{3, *}$ and K. C. Amanul Alam ${ }^{3}$ \\ 1 Department of Alternative Energy Technology, Faculty of Engineering and Technology, Al-Zaytoonah \\ University, P.O. Box 130, Amman 11733, Jordan; a.alahmer@zuj.edu.jo or a.alahmer@ttu.edu.jo \\ 2 Department of Mechanical Engineering, Faculty of Engineering, Tafila Technical University, P.O. Box 179, \\ Tafila 66110, Jordan \\ 3 School of Engineering, University of Tasmania, Private Bag 65, Hobart 7001, Australia; \\ amanul_alam@yahoo.com.au \\ * Correspondence: Xiaolin.wang@utas.edu.au; Tel.: +61-3-6226-2133
}

Received: 14 January 2020; Accepted: 19 February 2020; Published: 24 February 2020

\begin{abstract}
Performance assessment of a two-bed silica gel-water adsorption refrigeration system driven by solar thermal energy is carried out under a climatic condition typical of Perth, Australia. A Fourier series is used to simulate solar radiation based on the actual data obtained from Meteonorm software, version 7.0 for Perth, Australia. Two economic methodologies, Payback Period and Life-Cycle Saving are used to evaluate the system economics and optimize the need for solar collector areas. The analysis showed that the order of Fourier series did not have a significant impact on the simulation radiation data and a three-order Fourier series was good enough to approximate the actual solar radiation. For a typical summer day, the average cooling capacity of the chiller at peak hour (13:00) is around $11 \mathrm{~kW}$ while the cyclic chiller system coefficient of performance (COP) and solar system COP are around 0.5 and 0.3 , respectively. The economic analysis showed that the payback period for the solar adsorption system studied was about 11 years and the optimal solar collector area was around $38 \mathrm{~m}^{2}$ if a compound parabolic collector (CPC) panel was used. The study indicated that the utilization of the solar-driven adsorption cooling is economically and technically viable for weather conditions like those in Perth, Australia.
\end{abstract}

Keywords: adsorption chiller; silica gel; solar cooling; sconomic analysis

\section{Introduction}

Cooling demand has continued to increase in recent years, due to the need to achieve high thermal comfort in residential buildings. This has led to the wide application of vapor compression cooling systems, resulting in a significant increase in electricity peak loads in summer [1]. Therefore, researchers have put a lot of efforts into developing efficient, environmentally friendly air-conditioning systems driven by thermal energy sources such as solar, geothermal and industrial waste thermal energy. Recently, solar-powered adsorption chillers have attracted increasing attention because of the use of environmentally benign refrigerants such as water with zero ozone depletion potential, and ability to be driven by any type of low-grade thermal energy source. Silica gel-water adsorption chillers are more favorited for low-temperature solar energy under $80^{\circ} \mathrm{C}$ which can be obtained using flat-plate solar collectors (FPC), evacuated tube solar collectors (ETC) or compound parabolic collectors (CPC) [2-4]. Although solar-powered adsorption chillers have a very promising future, this technology is not yet widely commercialized due to low system coefficient of performance (COP) and high manufacturing cost of the chiller $[5,6]$. 
Many researchers have put a lot of effort into improving the system COP and specific cooling capacity (SCP) using different technologies such as heat and mass recovery, multi-bed and multi-stage technologies, and improvement of the structure of sorption beds [7-9]. These technologies substantially improved the performance of adsorption systems and hence a lot of studies have been conducted to investigate and improve the system performance of adsorption cooling systems. Chang et al. [10] experimentally investigated the cooling power and COP of a closed-type silica gel-water adsorption chiller under different operating conditions. A COP of 0.45 , cooling power of $4.3 \mathrm{~kW}$ and SCP of $176 \mathrm{~W} \cdot \mathrm{kg}^{-1}$ was achieved at hot water temperature, $80^{\circ} \mathrm{C}$, cooling water temperature, $30^{\circ} \mathrm{C}$ and chilled water temperature, $14^{\circ} \mathrm{C}$. Wang and Chua [11] studied a two-bed silica gel-water adsorption chiller with a water-circulation heat recovery scheme using a lumped parameter method. The results showed that the lumped parameter model was reliable to evaluate the chiller performance and optimize the design of adsorption chillers. Rezk and Al-Dadah [12] numerically evaluated the performance of a two-bed silica gel-water adsorption chiller with heat and mass recovery. This study showed that the chiller cooling capacity increased by $3 \%$ and COP reduced by $2.3 \%$. Deshmukh et al. [13] proposed a continuous three-bed silica gel water solar-adsorption cooling system with a liquid refrigerant storage tank. This system showed the ability to produce a cooling capacity of $0.8 \mathrm{~kW}$ for $24 \mathrm{~h}$. The average system COP and SCP reached 0.63 and $337.5 \mathrm{~kJ} \cdot \mathrm{kg}^{-1}$, respectively. Alsaqoor et al. [14] experimentally studied the effect of the switching time on a three-bed dual-evaporator silica gel-water adsorption chiller driven by waste heat from a cogeneration plant. The results showed that the highest cooling capacity was $90.5 \mathrm{~kW}$ and COP was 0.645 at a switching time of $900 \mathrm{~s}$. Chang et al. [15] studied a two-bed, closed-type, solar-powered, silica gel-water adsorption chiller. The chiller achieved a cooling capacity (CC) of $9 \mathrm{~kW}, \mathrm{COP}$ of 0.37 and SCP of $72 \mathrm{~W} \cdot \mathrm{kg}^{-1}$ adsorbent at a cooling water temperature of $30^{\circ} \mathrm{C}$, a hot water temperature of $80^{\circ} \mathrm{C}$, and chilled water inlet temperature of $14^{\circ} \mathrm{C}$.

The intermittent nature of solar radiation is one of the challenges for solar-driven adsorption refrigeration (SAR) systems. Hassan et al. [16] proposed continuous cold production in SAR systems. A dynamic analysis of the CTAR cycle (constant temperature adsorption refrigeration) was performed to compare with the theoretical operation. The results demonstrated that the constant temperature adsorption process could be achieved in the theoretical CTAR cycle. The isothermal process could be approached through enhancing heat transfer between the adsorption bed and the ambient environment during the pre-cooling process. The proposed solar-adsorption chiller achieved a COP of 0.402 , cooling capacity of $363.8 \mathrm{~W}$ and SCP of $1.82 \mathrm{~W} \cdot \mathrm{kg}^{-1}$ under continuous operating conditions. In a similar effort, modeling of a solar-adsorption chiller using activated carbon and methanol as the working pair was performed by Hassan et al. [17]. The chiller could produce $2.63 \mathrm{~kg}$ cold-water per day at $0{ }^{\circ} \mathrm{C}$ from water at $25^{\circ} \mathrm{C}$ per $\mathrm{kg}$ of adsorbent and achieved a COP of 0.66. Habib et al. [18] evaluated the effect of adsorbent-adsorbate pairs such as silica gel-water, activated carbon fiber (ACF)-ethanol and activated carbon-methanol on the adsorption chiller performance under Malaysia weather conditions. The results showed that the highest COP value was achieved in the silica gel-water cycle at the regeneration temperature below $70{ }^{\circ} \mathrm{C}$ while the $\mathrm{COP}$ was found to be highest in an ACF-ethanol adsorption cycle at the regeneration temperature above $70{ }^{\circ} \mathrm{C}$. Some authors numerically studied a solar thermal driven dual-mode, four-bed silica gel-water adsorption chiller under weather conditions typical of Durgapur, India [19]. At a source temperature above $60^{\circ} \mathrm{C}$, the chiller worked as a single-stage four-bed mode; but functioned as a two-stage adsorption mode at the driving source temperature below $60^{\circ} \mathrm{C}$. At a cooling water temperature of $30^{\circ} \mathrm{C}$, the two-stage mode chiller produced a cooling effect at a source temperature as low as $40^{\circ} \mathrm{C}$. Zhai et al. [20] investigated a solar-powered adsorption air-conditioning system that consisted of a $150 \mathrm{~m}^{2}$ solar collector and two adsorption chillers with a capacity of $8.5 \mathrm{~kW}$ each under weather conditions typical of Shanghai, China. The system achieved a daily average solar COP of 0.15 and a system COP of 0.35 , respectively. Sumathy et al. [21] optimized crucial parameter effects on an adsorption cooling system driven by a flat-plate solar collector. The results showed a maximum SCP at a collector area of $150 \mathrm{~W} \cdot \mathrm{m}^{-2}$. 
As detailed in the above literature, the solar-adsorption chiller system has been widely studied in general. However, there is a lack of research in the literature about the economics of solar-driven adsorption chillers. This remains a very complex issue because weather conditions vary from one location to another. Tsoutsos et al. [22] conducted an economic analysis of absorption versus adsorption solar thermal cooling systems. The results showed that adsorption systems were more expensive than absorption systems by $50 \%$ in terms of capital cost. However, the adsorption chiller could be operated under low solar energy temperatures which implied that the adsorption chiller had greater potential. Ugla et al. [23] compared the performance of conventional vapor-compression, solar $\mathrm{LiBr}-\mathrm{H}_{2} \mathrm{O}$ absorption, and solar photovoltaic (PV) vapor-compression. Payback Period (PbP) and the Net Present Value (NPV) were used to investigate a commercial building in Khobar City, Saudi Arabia. The results showed that solar absorption systems were more economically feasible in comparison to solar PV-vapour-compression systems. Furthermore, the feasibility of both solar-powered systems improved as the size of the commercial building and the electricity consumption rate increased. This indicated an economic potential for solar-adsorption systems due to the similarity between the adsorption and absorption systems. Alahmer et al. [24] evaluated a CPC solar-adsorption cooling system using Transient System Simulation (TRNSYS) software (Version 17). The study indicated that this form of adsorption cooling could potentially be economically used in cities with high solar irradiation.

This paper presents dynamic modeling of a solar thermally driven two-bed silica gel-water continuous adsorption cooling system which is driven by a compound parabolic concentrator (CPC). Perth city in Western Australia (latitude of $32^{\circ} \mathrm{N}$, longitude of $115.8^{\circ} \mathrm{E}$ and an elevation of $0.0 \mathrm{~m}$ ) is selected for the case study to evaluate the economic feasibility of adsorption air-conditioning systems. In Perth, the daily maximum ambient temperature is around 30 to $40{ }^{\circ} \mathrm{C}$ for three to four months in summer which substantially increases the electricity consumption for air-conditioning systems. Meanwhile, Perth city has one of the world's highest radiation intensities which averages over 5.4 peak sun hours each day up to over 8 peak sun hours [25]. This provides excellent potential for solar cooling. A mathematic model, Fourier series is proposed to simulate solar radiation data according to the actual solar radiation obtained from Meteonorm software version 7.0. An economic analysis using the PbP and Life-Cycle Saving (LCS) methods is conducted to study the economic potential of applying solar-adsorption cooling technologies for weather conditions like Perth city. The optimum solar collect area is studied. The research work provides useful information for decision-makers and engineers in the adoption and design of solar-adsorption cooling technologies.

\section{System Description}

Figure 1 presents a schematic drawing of an adsorption cooling system with CPC solar collectors. The system is mainly composed of a conventional two-bed adsorption chiller (including one adsorber/desorber pairs, an evaporator, a condenser, and four refrigerant valves), solar thermal system CPCs, metallic tubes for cold and hot working fluids, and a cooling tower.

Water evaporates from the evaporator and is adsorbed by the adsorber through valve V1, which is called the "evaporator-adsorption process". At the same time, desorbed water vapor flows to the condenser through valve V4, which is known as the "desorption-condensation process". The adsorption cooling chiller used in this study is a conventional two-bed silica gel-water adsorption system proposed by Alam et al. [26] and the detailed operational procedure of the adsorption chiller system was presented in the literature [26]. 


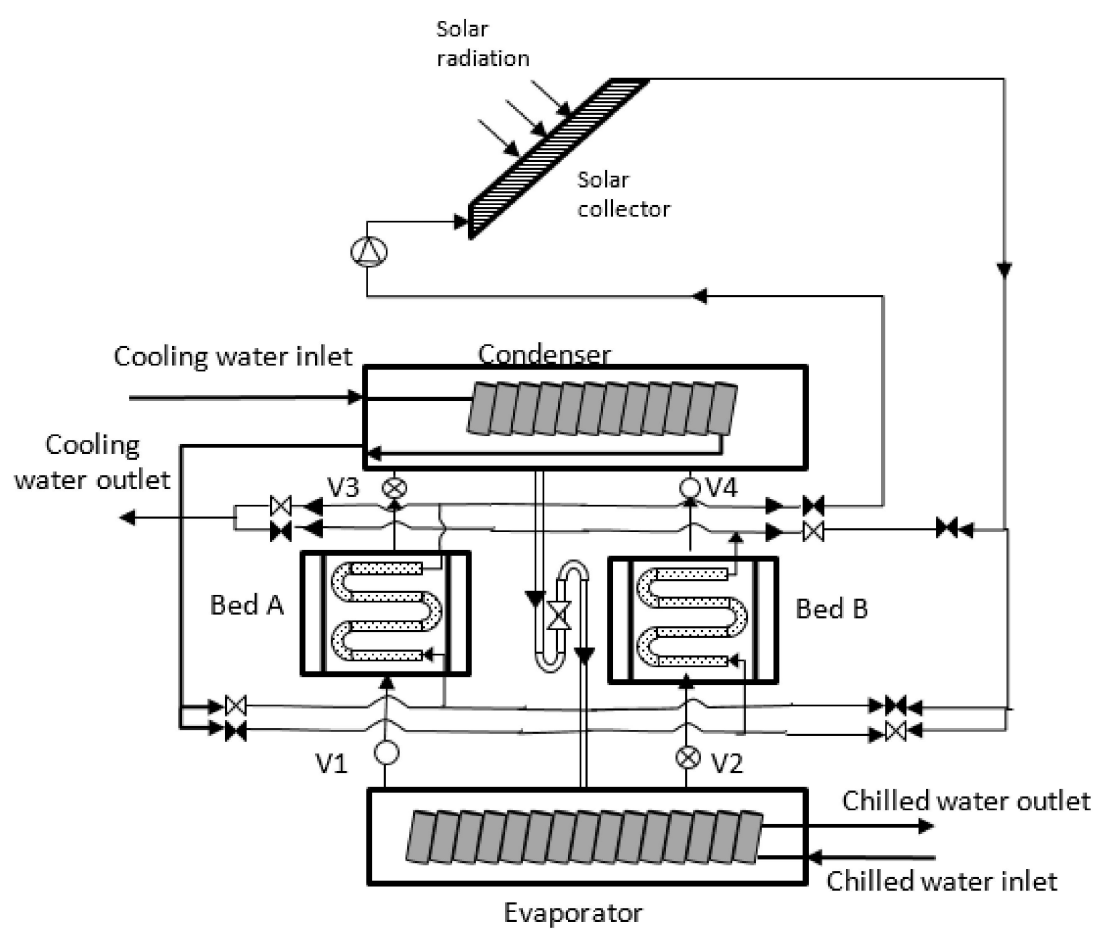

Figure 1. A schematic drawing of an adsorption cooling chiller driven by the compound parabolic collector (CPC) solar collector panel.

\section{Mathematical Modelling}

\subsection{Correlation Equation of Solar Radiation Data}

The radiation database consists of hourly measurements; however, continuous data is required for the simulation procedure. Therefore, Fourier series are used to simulate the solar radiation data according to the actual hourly-based solar radiation. The objective of using the Fourier series expansion is to provide suitable solar radiation predictions to a large ecosystem model. Then, the actual radiation intensity pattern of Perth city can be emulated. The outputs are expected to be similar to reality, in a statistical manner, so that appropriate amounts of energy are allocated in the virtual ecosystem.

In general, the solar radiation can be described as a function of the Sun-Earth distance, the Earth's inclination and the Sun's zenith angle. The proposed model, instead of studying the atmosphere and the clouds, studies the historical on-surface radiation measurements. The variable of interest is the daily overall solar energy, $\left(\mathrm{Wh} \cdot \mathrm{m}^{-2}\right)$. One year's daily overall solar energy is considered as a signal, and one signal is analyzed at a time. Multiple years' signals of one city bear the same statistical characters. The statistical characters are summarized with a set of models which would be used to synthesize new annual daily overall solar energy on demand. The synthesized data should be statistically similar to the original set. The output of this model represents an averaged, typical trend of the history, rather than forecast any future extreme situations.

The historical solar radiation records for Perth city were acquired from Perth Meteorology. The data was recorded as hourly overall energy, in $\mathrm{kJ} \cdot \mathrm{m}^{-2}$. For each day, hourly values were summed up to obtain the daily overall solar energy $\left(\mathrm{Wh} \cdot \mathrm{m}^{-2}\right)$. The identical analysis procedure was performed for each day of Perth city, resulting in one individual model for Perth city depicting the statistical characteristics of the local solar radiation pattern.

To simplify the calculation, only a simple sine function is considered in the present analysis. The solar radiation, I can be expressed by: 


$$
I=\sum_{k=1}^{K} a_{k} \sin \left(k \pi x_{i}\right) \text { For } K=1,2,3, \ldots
$$

The objective function is:

$$
Z=\sum_{i=1}^{N}\left[y_{i}-\sum_{k=1}^{K} a_{k} \sin \left(k \pi x_{i}\right)\right]^{2} \rightarrow \text { Min }
$$

A derivative of the objective function with the coefficient $a_{k}$ is:

$$
\frac{\partial z}{\partial a_{k}}=-2 \sum_{i=1}^{N}\left[y_{i}-\sum_{k=1}^{K} a_{k} \sin \left(k \pi x_{i}\right)\right] \sin \left(k \pi x_{i}\right)
$$

where the coefficients $a_{k}$ are improved by iterative operation until the desired level of the fitting is obtained. $A$ is the parameter to control the convergence and is set at 0.01 in this analysis. The iterative equation for the coefficient $a_{k}$ is shown below:

$$
a_{k, \text { new }}=a_{k, \text { old }}-A \frac{\partial z}{\partial a_{k}}
$$

Initial values for all $a_{k}$ are set at 0 . A convergence criterion to stop the program is set as:

$$
\sum_{i=1}^{N}\left\|\frac{\partial z}{\partial a_{i}}\right\| \leq t o l
$$

where tol is set at $10^{-8}$ in the present study.

\subsection{Empirical Equation for Day Temperature Data}

The day temperature function is calculated based on the following equation [27]:

$$
T_{a m}=\frac{\left(T_{\max }+T_{\min }\right)}{2}+\frac{T_{\max }-T_{\min }}{2} \times \sin \left[\frac{\pi \times(\text { Daytime }- \text { Sunrisetime }-i)}{\text { Daylength }}\right]
$$

where $i$ is the time difference between the times of maximum radiation and maximum temperature. In the present case, it is selected as 1 hour.

\subsection{Energy Balance for Adsorption Chiller}

In the bed-energy balance analysis, the assumptions include uniform temperatures, pressures, and concentrations throughout the bed, thermal equilibrium in the adsorber and constant thermal properties such as density and specific heat for the adsorbent and water vapor. Therefore, the energy balance equation for the sorption beds is expressed by:

$$
\begin{gathered}
\frac{d}{d t}\left\{\left(M_{M} C_{M}+M_{s} C_{s}+M_{s} q C_{r, v}\right) T_{\text {bed }}\right\}=Q_{s t} M_{s} \frac{d q}{d t}+\delta . M_{s} C_{r, v} \frac{d q}{d t}\left(T_{e v a}-T_{\text {bed }}\right)+\dot{m}_{f} C_{f}\left(T_{\text {bed,in }}-T_{\text {bed,out }}\right) \\
T_{\text {bed,out }}=T_{\text {bed }}+\left(T_{\text {bed,in }}-T_{\text {bed }}\right) e^{\left(\frac{-U A_{\text {bed }}}{\dot{m}_{f} C_{f}}\right)}
\end{gathered}
$$

where $\delta$ equals 0 or 1 refers to the desorption and adsorption process. It depends on whether the sorption bed works as a desorber or adsorber. The left-hand side in Equation (7) indicates the internal energy change of the sorption bed including adsorbent material, vapor within the adsorbent bed and metal used in bed. While the right side consists of desorption/adsorption heat, energy transfers from 
the evaporator to bed or from the bed to the condenser, and energy transfers between the bed and cooling or heating fluid during the sorption process.

The energy balance equation for the condenser is expressed by:

$$
\begin{aligned}
& \frac{d}{d t}\left\{\left(M_{c o n, M} C_{c o n, M}+M_{c o n, r} C_{r, l}\right) T_{c o n}\right\} \\
& =-L \cdot M_{c o n} \frac{d q_{d}}{d t}+M_{s} C_{r, v} \frac{d q_{d}}{d t}\left(T_{c o n}-T_{b e d}\right) \\
& +\dot{m}_{f, \text { con }} C_{f}\left(T_{\text {con, in }}-T_{\text {con,out }}\right) \\
& T_{\text {con }, \text { out }}=T_{\text {con }}+\left(T_{\text {con }, \text { in }}-T_{\text {con }}\right) e^{\left(\frac{-U A_{c o n}}{\dot{m}_{f, c o n} C_{f}}\right)}
\end{aligned}
$$

Equation (9) states that the internal energy change of the condenser material and the refrigerant condensation within the condenser is equal to the energy released during the condensation process and the energy transfers from the bed to the condenser, with the addition of energy rejected from the condenser.

The energy balance equation for the evaporator is expressed by:

$$
\begin{aligned}
& \frac{d}{d t}\left\{\left(M_{\text {eva }, M} C_{\text {eva }, M}+M_{\text {eva }, r} C_{r, l}\right) T_{\text {eva }}\right\} \\
& =-L \cdot M_{s} \frac{d q_{a}}{d t}+M_{s} C_{r, l} \frac{d q_{d}}{d t}\left(T_{\text {eva }}-T_{\text {con }}\right) \\
& +\dot{m}_{f, \text { chill }} C_{f}\left(T_{\text {chill,in }}-T_{\text {chill,out }}\right) \\
& T_{\text {chill,out }}=T_{\text {eva }}+\left(T_{\text {chill,in }}-T_{\text {eva }}\right) e^{\left(\frac{-U A_{\text {evva }}}{\bar{m}_{f, \text { chill }}}\right)}
\end{aligned}
$$

Equation (11) indicates the change of internal energy in the evaporator process is equal to the energy transfer from the condenser to the evaporator, the energy transferred to the adsorber and energy supplied from the chilled water.

The mass balance equation of the refrigerant inside the evaporator is expressed by:

$$
\frac{d M_{e v a, r}}{d t}=-M_{s}\left(\frac{d q_{a}}{d t}+\frac{d q_{d}}{d t}\right)
$$

The vapor adsorption rate in the sorption bed is calculated using the linear driving force kinetic equation:

$$
\frac{d q}{d t}=15 \frac{D_{s o} e^{\frac{-E_{a}}{R T}}}{R_{P}^{2}}\left(q^{*}-q\right)
$$

The numerical values of $D_{s o}$ and $E_{a}$ for silica gel water are evaluated experimentally in the literature [22]. Adsorption equilibrium is expressed by a modified Freundlich equation that has been proven in the literature [25]:

$$
\begin{gathered}
q^{*}=A A\left[\frac{P_{S}\left(T_{v}\right)}{P_{S}\left(T_{b e d}\right)}\right]^{B B} \\
A A=A_{0}+A_{1} T+A_{2} T^{2}+A_{3} T^{3} \\
B B=B_{0}+B_{1} T+B_{2} T^{2}+B_{3} T^{3}
\end{gathered}
$$

The constants of $\mathrm{A}_{0} \sim \mathrm{A}_{3}$ and $\mathrm{B}_{0} \sim \mathrm{B}_{3}$ are adapted from the literature [26] and listed below:

$A_{0}=-6.5314 \mathrm{~kg} \times \mathrm{kg}^{-1}$ of dry adsorbent

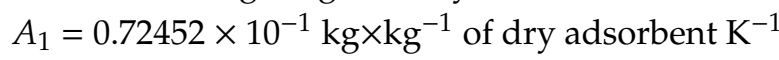

$A_{2}=-0.23951 \times 10^{-3} \mathrm{~kg} \times \mathrm{kg}^{-1}$ of dry adsorbent $\mathrm{K}^{-2}$

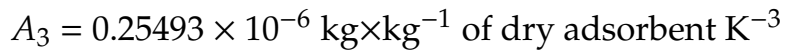

$B_{0}=-15.587$

$B_{1}=015915 \mathrm{~K}^{-1}$ 
$B_{2}=-0.50612 \times 10^{-3} \mathrm{~K}^{-2}$

$B_{3}=0.5329 \times 10^{-6} \mathrm{~K}^{-3}$

The energy balance equation for each solar collector is expressed by:

$$
M_{C r M, i} \frac{d T_{c r, i}}{d t}=\eta_{i} A_{c r, i} I+\dot{m}_{f, c r} C_{f}\left(T_{c r, i, i n}-T_{c r, i, o u t}\right)
$$

Due to a small temperature difference between the heating and cooling fluid, the log mean temperature difference (LMTD) method is used to model the outlet temperature of the heat source or heat sink, and the outlet temperature is given by:

$$
T_{c r, i, o u t}=T_{c r, i}+\left(T_{c r, i, i n}-T_{c r, i}\right) e^{\left(-\frac{U_{c p, i} A_{c p, i}}{\dot{m}_{f, c r} c_{f}}\right)}
$$

where, $i=1$, number of pipes in the solar collector.

\subsection{Performance Analysis}

Collector efficiency is calculated using the equation reported by Clausse et al. [28]:

$$
\eta_{S C}=0.75-2.57\left(\frac{\bar{T}_{H W}-T_{a m}}{I}\right)-4.67\left(\frac{\bar{T}_{H W}-T_{a m}}{I}\right)^{2}
$$

where; $\bar{T}_{H W}$ is the mean temperature for hot fluid and it is evaluated by: $\bar{T}_{H W}=\left(\frac{T_{H W, \text { in }}+T_{H W, o u t}}{2}\right)$; $I$ : solar radiation.

The cyclic average cooling capacity (CACC) is determined by:

$$
\text { ACC }=\frac{\dot{m}_{\text {chill }} C_{\text {chill, } f} \int_{\text {begin of cycle time }}^{\text {end of cycle time }}\left(T_{\text {chill,in }}-T_{\text {chill,out }}\right) d t}{t_{\text {cycle }}}
$$

The cycle COP is defined as a ratio of cooling capacity to total required thermal energy and is calculated for each single cycle; while the solar system $\mathrm{COP}$ in a cycle $\left(\mathrm{COP}_{\mathrm{SC}}\right.$, cycle $)$ is defined as a ratio of cooling capacity to the net solar energy input; and $\mathrm{COP}_{\mathrm{SC}}$, net is calculated on the period of cold production. These COPs are calculated as [24,27]:

$$
\begin{aligned}
& \operatorname{COP}_{\text {cycle }}=\frac{\int_{\text {begin of cycle time }}^{\text {end of cycle time }} \dot{m}_{\text {chill }} C_{\text {chill, } f}\left(T_{\text {chill,in }}-T_{\text {chill,out }}\right) d t}{\int_{\text {begin of cycle time }}^{\text {end of cycle time }} \dot{m}_{f} C_{f}\left(T_{d, \text { in }}-T_{d, \text { out }}\right) d t} \\
& C O P_{S C, \text { cycle }}=\frac{\int_{\text {begin of cycle time }}^{\text {end of chcle time }} \dot{m}_{\text {chill }} C_{\text {chill, }, f}\left(T_{\text {chill, in }}-T_{\text {chill,out }}\right) d t}{\int_{\text {begin of of cycle time }}^{\text {end }} n \cdot A_{\text {cr }} I d t} \\
& \operatorname{COP}_{S C, \text { cycle }}=\frac{\int_{\text {Sunrise time }}^{\text {Chiller }} \dot{m}_{\text {chill }} C_{\text {chill, } f}\left(T_{\text {chill, in }}-T_{\text {chill,out }}\right) d t}{\int_{\text {Sunrise time }}^{\text {Chile }}{ }^{n} \text { n. } A_{\text {cr I I }} \text { It }}
\end{aligned}
$$

After sunset, the $C O P_{S C}$, net equation becomes

$$
\operatorname{COP}_{S C, \text { net }}=\frac{\int_{\text {Sunrise time }}^{\text {Chiller stop time }} \dot{m}_{\text {chill }} C_{\text {chill, }, f}\left(T_{\text {chill,in }}-T_{\text {chill,out }}\right) d t}{\int_{\text {Sunrise time }}^{\text {Sunse time }} n \cdot A_{\text {cr I It }}}
$$

where $I$ is the solar irradiation intensity, $A_{c r}$ is one collector area, and $n$ is the number of collectors. 
The above differential equations are solved using implicit finite difference approximation with a tolerance of $10^{-4}$ for the convergence calculation. Details of the simulation procedure were discussed in our previous publication [7]. The flow chart of a solar-driven two-bed adsorption chiller model was demonstrated in Figure 2. Table 1 lists the operating conditions and design parameters used in the present simulation. The assumptions include: (i) the temperature and pressure are uniform in each adsorber; (ii) no heat loss to the environment as the system is well insulated; (iii) the thermal energy transfer along the pipes connecting the system components is neglected; and (iv) the pressure differences between the sorption bed and the condenser or between the sorption bed and the evaporator are neglected [29].

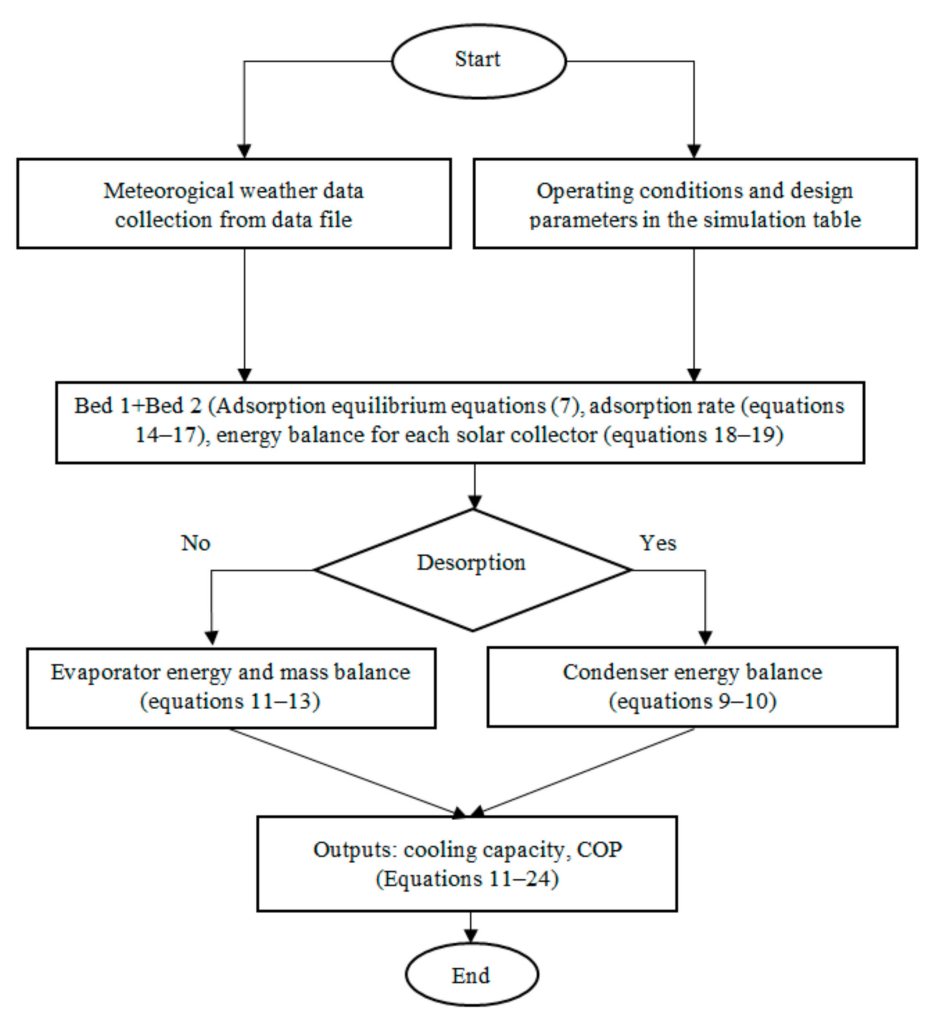

Figure 2. Flow chart of the solar adsorption chiller system simulation.

Table 1. Operating conditions and design parameters.

\begin{tabular}{crc}
\hline Symbol & Parameter & Nominal Value \\
\hline $\mathrm{A}_{\text {bed }}$ & Sorbent bed heat transfer area & $2.415 \mathrm{~m}^{2}$ \\
\hline $\mathrm{U}_{\text {bed }}$ & Heat transfer coefficient of the bed & $1724.14 \mathrm{~W} \cdot \mathrm{m}^{-2} \cdot \mathrm{K}^{-1}$ \\
\hline $\mathrm{A}_{\mathrm{eva}}$ & Heat transfer area of the evaporator & $1.91 \mathrm{~m}^{2}$ \\
\hline $\mathrm{U}_{\mathrm{eva}}$ & Heat transfer coefficient of the evaporator & $2557.54 \mathrm{~W} \cdot \mathrm{m}^{-2} \cdot \mathrm{K}^{-1}$ \\
\hline $\mathrm{M}_{\mathrm{eva}, \mathrm{M}}$ & Heat exchanger tube weight inside the evaporator & $12.45 \mathrm{~kg}$ \\
\hline $\mathrm{A}_{\mathrm{con}}$ & Heat transfer area of the condenser & $3.73 \mathrm{~m}^{2}$ \\
\hline $\mathrm{U}_{\mathrm{con}}$ & Heat transfer coefficient of the condenser & $4115.23 \mathrm{~W} \cdot \mathrm{m}^{-2} \cdot \mathrm{K}^{-1}$ \\
\hline $\mathrm{W}_{\mathrm{con}, \mathrm{M}}$ & Heat exchanger tube weight inside the condenser & $24.28 \mathrm{~kg}$ \\
\hline $\mathrm{A}_{\mathrm{cr}}$ & One collector area & $2.415 \mathrm{~m}{ }^{2}$ \\
\hline $\mathrm{M}_{\mathrm{cp}}$ & Weight of each pipe including absorber sheet & $0.4913 \mathrm{~kg}$ \\
\hline $\mathrm{N}_{\mathrm{p}}$ & Number of pipes in each collector & 9 \\
\hline$\dot{\mathrm{m}}_{\mathrm{f}, \text { hot }}$ & Total mass flow rate to the CPC panel or the desorber & $1.3 \mathrm{~kg} \cdot \mathrm{s}^{-1}$ \\
\hline
\end{tabular}


Table 1. Cont.

\begin{tabular}{ccc}
\hline Symbol & Parameter & Nominal Value \\
\hline$\dot{\mathrm{m}}_{\mathrm{f}, \text { cool }}$ & Cooling water mass flow rate to the adsorber & $1.3 \mathrm{~kg} \cdot \mathrm{s}^{-1}$ \\
\hline $\mathrm{M}_{\mathrm{s}}$ & Silica gel weight in each bed & $47 \mathrm{~kg}$ \\
\hline $\mathrm{M}_{\mathrm{eva} ; \mathrm{r}}$ & Liquid refrigerant mass in the evaporator initially & $50 \mathrm{~kg}$ \\
\hline$\dot{\mathrm{m}}_{\mathrm{f} ; \text { cond }}$ & Cold water mass flow rate to the condenser & $1.3 \mathrm{~kg} \cdot \mathrm{s}^{-1}$ \\
\hline$\dot{\mathrm{m}}_{\mathrm{f} ; \mathrm{chill}}$ & Chilled water mass flow rate & $0.7 \mathrm{~kg} \cdot \mathrm{s}^{-1}$ \\
\hline $\mathrm{W}_{\mathrm{con}, \mathrm{r}}$ & Condensed refrigerant inside the condenser & $1.0 \mathrm{~kg}$ \\
\hline $\mathrm{C}_{\mathrm{r}, \mathrm{l}}$ & Specific heat of the water in the liquid phase & $4.18 \times 10^{3} \mathrm{~J} \cdot \mathrm{kg}^{-1} \cdot \mathrm{K}^{-1}$ \\
\hline $\mathrm{C}_{\mathrm{r}, \mathrm{v}}$ & Specific heat of the water in the vapor phase & $1.89 \times 10^{3} \mathrm{~J} \cdot \mathrm{kg}^{-1} \cdot \mathrm{K}^{-1}$ \\
\hline $\mathrm{C}_{\mathrm{s}}$ & Specific heat of the silica gel & $924 \mathrm{~J} \cdot \mathrm{kg}^{-1} \cdot \mathrm{K}^{-1}$ \\
\hline $\mathrm{L}$ & Latent heat of water & $2.6 \times 10^{6} \mathrm{~J} \cdot \mathrm{kg}^{-1}$ \\
\hline $\mathrm{Q}_{\mathrm{st}}$ & Adsorption or isosteric heat & $2.81 \times 10^{6} \mathrm{~J} \cdot \mathrm{kg}^{-1}$ \\
\hline $\mathrm{R}$ & Gas constant of the water & $462 \mathrm{~J} \cdot \mathrm{kg}^{-1} \cdot \mathrm{K}^{-1}$ \\
\hline $\mathrm{E}_{\mathrm{a}}$ & Activation energy & $2.33 \times 10^{6} \mathrm{~J} \cdot \mathrm{kg}^{-1}$ \\
\hline $\mathrm{D}_{\mathrm{S} 0}$ & Diffusion coefficient & $2.54 \times 10^{-4} \mathrm{~m}^{2} \cdot \mathrm{s}^{-1}$ \\
\hline $\mathrm{Rp}$ & Diameter of the silica gel particle & $0.35 \times 10^{-3} \mathrm{~m}$ \\
\hline $\mathrm{T}_{\mathrm{cool}}$ & Cooling source temperature & $30^{\circ} \mathrm{C}$ \\
\hline $\mathrm{T}_{\mathrm{chill}, \text { in }}$ & Chilled water inlet temperature & $1{ }^{\circ} \mathrm{C}$ \\
\hline & &
\end{tabular}

\subsection{Economic Analysis}

Life-Cycle Saving (LCS) is employed for economic analysis to evaluate economic potential of the solar thermal driven adsorption cooling system and to find the optimum solar collector area. The LCS of the solar system over a conventional system is defined as the difference between the reduction in fuel costs and the increase in expenses resulting from the additional investment for the solar system. It is calculated by the following equation [30,31]:

$$
L C S=P_{1} C_{F} L F_{t}-P_{2}\left(C_{A} A_{c}+C_{E}\right)
$$

where $P_{1}$ refers to the factor of the life-cycle fuel cost over the first year fuel cost savings; $P_{2}$ is a factor of life cycle of the additional capital investment over the initial investment; $C_{A}$ is the solar energy investment cost that is directly proportional to the collector area; $C_{E}$ is the solar energy investment cost that is independent of the collector area; $C_{F}$ is the unit cost of delivered conventional energy for the first year of analysis; $L$ is the total load, and $F t$ is the total solar fraction of the solar system. More details to evaluate $P_{1}$ and $P_{2}$ can be found in the literature [31].

The following assumptions are taken to estimate the costs of using a solar adsorption chiller [32]:

- The initial investment cost of the solar-adsorption cooling system is estimated and listed in Table $2[22,33-35]$

- The life span of the cooling system is set as 20 years according to available products in the market

- The period of the loan is 15 years

- In Australian markets, the inflation rate in fuel price and the interest rate is around $2.8 \%$ and 12 $\%$, respectively

- The salvage factor for the auxiliary cooling system is assumed to be $20 \%$ of the capital cost

- The maintenance factor is assumed to be $1.1 \%$ of the capital cost for the auxiliary cooling system

- The electricity price is $0.33 \mathrm{USD} \mathrm{kWh}^{-1}$ in the Perth market 
Table 2. The initial capital cost of the main equipment [22,33-35].

\begin{tabular}{ccc}
\hline Components & Cost & Unit \\
\hline Adsorption chiller & 2100 & $\mathrm{US} \$ \times \mathrm{kW}^{-1}$ \\
Solar collector [33] & 260 & $\mathrm{US} \$ \times \mathrm{m}^{-2}$ \\
Storage tank [22] & 600 & $\mathrm{US} \$ \times \mathrm{m}^{-3}$ \\
Cooling tower [34] & 68 & $\mathrm{US} \$ \times \mathrm{kW}^{-1}$ \\
Auxiliary heater [22] & 50 & $\mathrm{US} \$ \times \mathrm{kW}^{-1}$ \\
Pumps [34,35] & $881 \times \mathrm{Wp}^{0.4 *}$ & $\mathrm{US} \$$ \\
\hline &
\end{tabular}

The simple Payback Period ( $\mathrm{PbP})$ method is used to analyze the feasibility of the solar thermal adsorption cooling system. It considers the time required to recover initial investment costs from the savings in electricity consumption by using this proposed solar cooling system. $\mathrm{PbP}$ is calculated by [30,31]:

$$
P b P=\frac{\log \left[1+\frac{C}{E} \frac{i}{100}\right]}{\log \left[1+\frac{i}{100}\right]}
$$

where $i$ is the change in energy prices relative to general inflation in the country or to energy inflation alone, $C$ is the initial investment cost of installing the solar cooling equipment (USD) and $E$ is the annual energy saving in USD which represents the difference between the cost of the solar cooling and conventional electric cooling systems.

\section{Results and Analysis}

The mathematical model of the adsorption chiller has been validated in our previous publications $[10,36]$. Comparison results in the literature show that the model is reliable in terms of the chiller performance analysis. Therefore, the adsorption model is directly used in the following analysis without further experimental validation. The design parameters and working conditions of the whole system are listed in Table 1.

\subsection{Ambient Temperature and Global Radiation of Perth City}

Weather data is obtained using Meteonorm software, version 7.0 for Perth city, Australia. Figure 3 shows the average variation of global radiation and ambient temperature in Perth in 2017. The results show that peak ambient temperature and global radiation were higher than $35^{\circ} \mathrm{C}$ and $1100 \mathrm{Wh} \cdot \mathrm{m}^{-2}$, respectively, during the months November to March. This confirms that there is a need for cooling in Perth for more than four months of the year and that solar radiation has a good potential for solar thermal cooling systems for residential and commercial buildings.

Figure 4 demonstrates the simulated global radiation for a typical day in January in Perth city using different orders of Fourier series. The results show that radiation intensity increases very quickly during the daytime from $400 \mathrm{~W} \cdot \mathrm{m}^{-2}$ at $8: 00 \mathrm{am}$ to $1020 \mathrm{~W} \cdot \mathrm{m}^{-2}$ at $13: 00$, and then gradually drops to $400 \mathrm{~W} \cdot \mathrm{m}^{-2}$ at 17:00, which matches very well with the ambient air temperature in Perth whenever the daytime temperature is very high and cooling is required. The highest global radiation is achieved at midday (13:00) with a radiation intensity of $1020 \mathrm{~W} \cdot \mathrm{m}^{-2}$. Comparison between the fitted and actual average hourly global solar radiation shows that the order of the Fourier series function does not have a strong impact on curve fitting for global radiation data. Three orders of the Fourier series function are sufficient to accurately match the actual radiation data. 


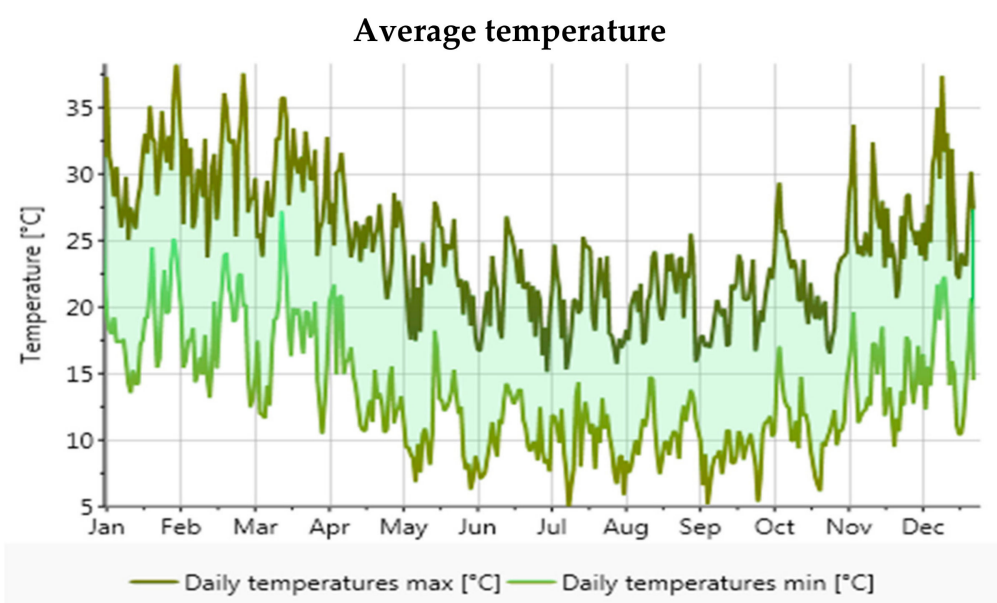

(a)

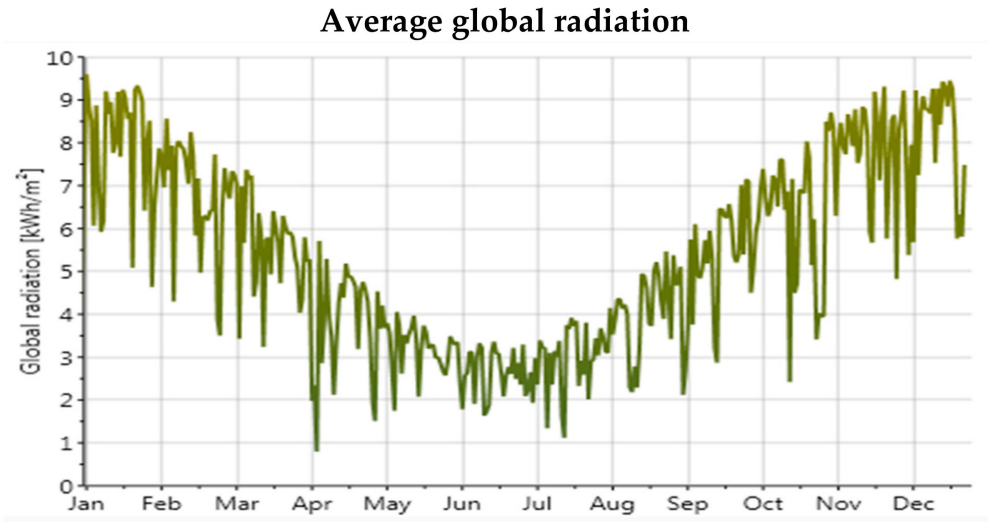

(b)

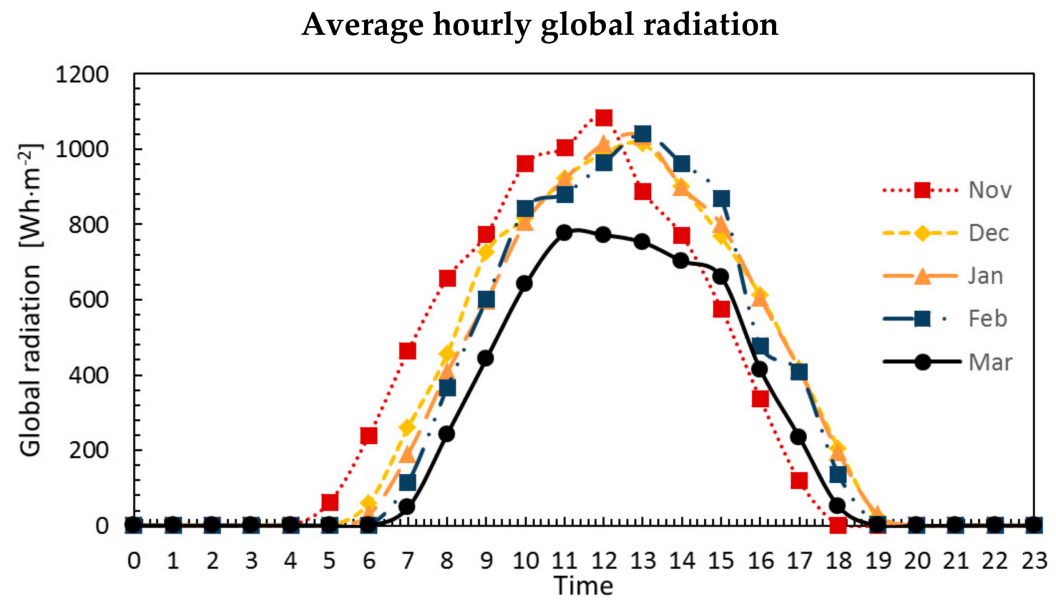

(c)

Figure 3. Average variation of ambient temperature and global radiation in Perth (Average temperature (a); Average global radiation (b); Average hourly global radiation (c).

\subsection{Outlet Temperatures History}

Figure 5 shows temperature profiles for hot water at the outlet of solar collectors and beds. The cycle time is $1500 \mathrm{~s}$, and the total number of solar collectors is 15 . It was observed that the water temperature at the collector outlet reached up to $90{ }^{\circ} \mathrm{C}$ while the water temperature at the bed outlet reached up to $80^{\circ} \mathrm{C}$. The temperature profiles show that the temperature of the hot water at the solar collector outlet (e.g., desorption bed inlet) stays above $60^{\circ} \mathrm{C}$ between 9:00 and 17:00. This indicates 
that the adsorption chiller can be driven by the solar collector and provide cooling for most of the daytime. Figure $5 \mathrm{~b}$ shows the temperatures at the hot water outlet of the solar collectors and sorption beds during a peak hour. The results show that the water temperature at the collector outlet is even above $80^{\circ} \mathrm{C}$ which can effectively drive the adsorption chiller.

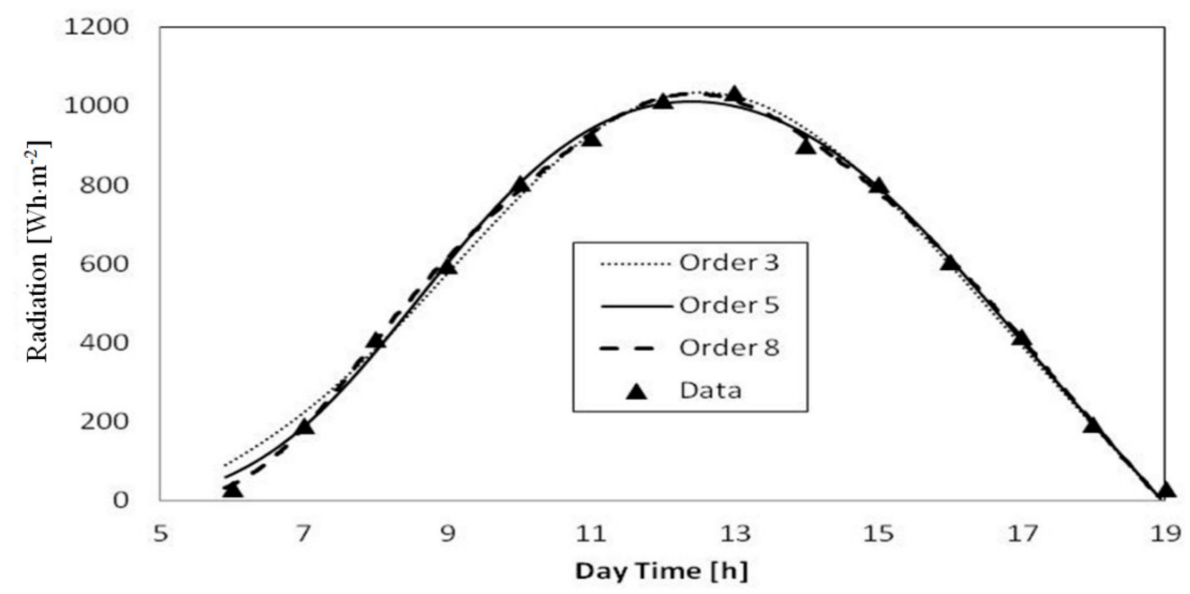

Figure 4. Simulated global radiation at different orders of the Fourier series in Perth.

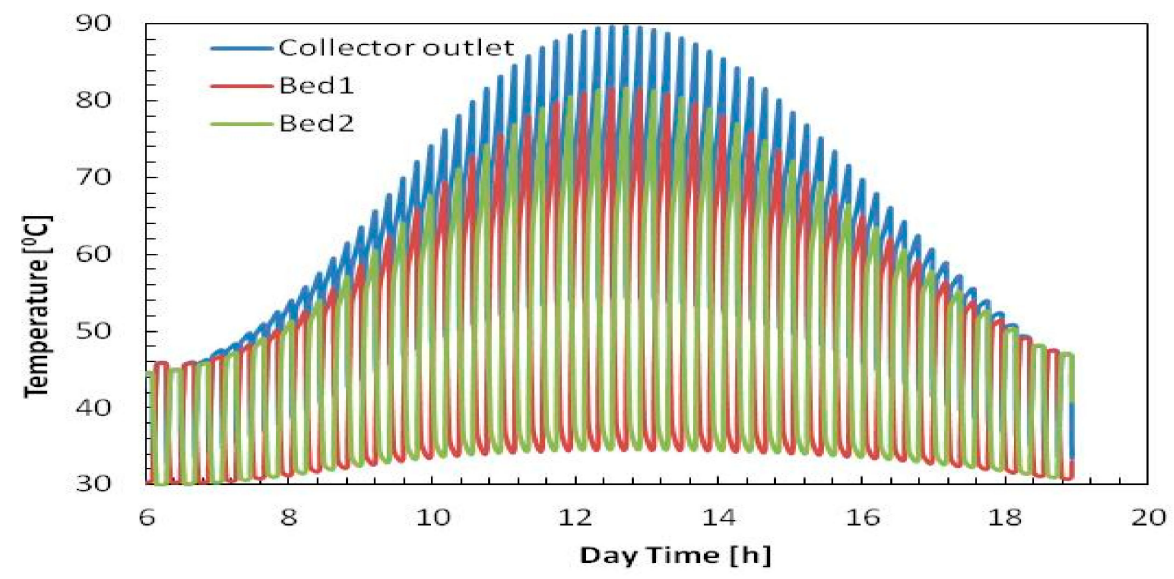

(a)

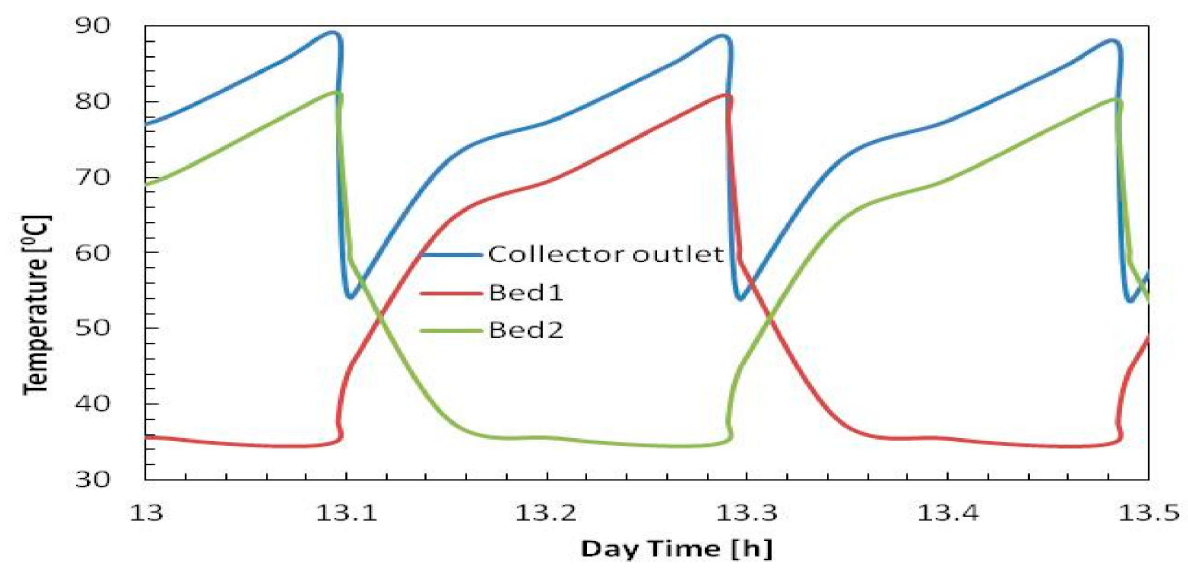

(b)

Figure 5. Temporal histories of hot water temperature at the outlet of the solar collectors and beds for a cyclic time of 1500 s, (a) day time; (b) peak time. 
Figure 6 shows water temperature profiles at evaporator and condenser outlets in the solar-driven two-bed adsorption chiller for a typical day in January in Perth city between 13:00 and 14:00. The water temperature trends agree well with the conventional adsorption chiller $[10,36]$. The water temperatures at the outlets of the adsorption beds, evaporator and condenser are normally applied to characterize the adsorption/desorption behavior. During the cooling process, the chilled water outlet temperature drops quickly at the beginning of the adsorption process because the adsorber is empty and the adsorption rate is high. As the vapor is adsorbed by the adsorbent (silica gel) in the adsorber, the adsorption rate decreases and hence the falling temperature rate at the chilled water outlet generally slowed down. Therefore, the drop in the chilled water outlet temperature slows down. When the adsorber is saturated, it enters the switching process after which the adsorber is switched to the desorption stage, and the empty desorption bed is switched to the adsorption stage to provide cooling. The next adsorption process starts in the empty adsorber. The chilled water outlet temperature varies between 9 and $12{ }^{\circ} \mathrm{C}$ while the condenser water outlet temperature varies between 30 and $34^{\circ} \mathrm{C}$. To achieve high system performance, the long cycle time is recommended to improve the adsorption/desorption process.

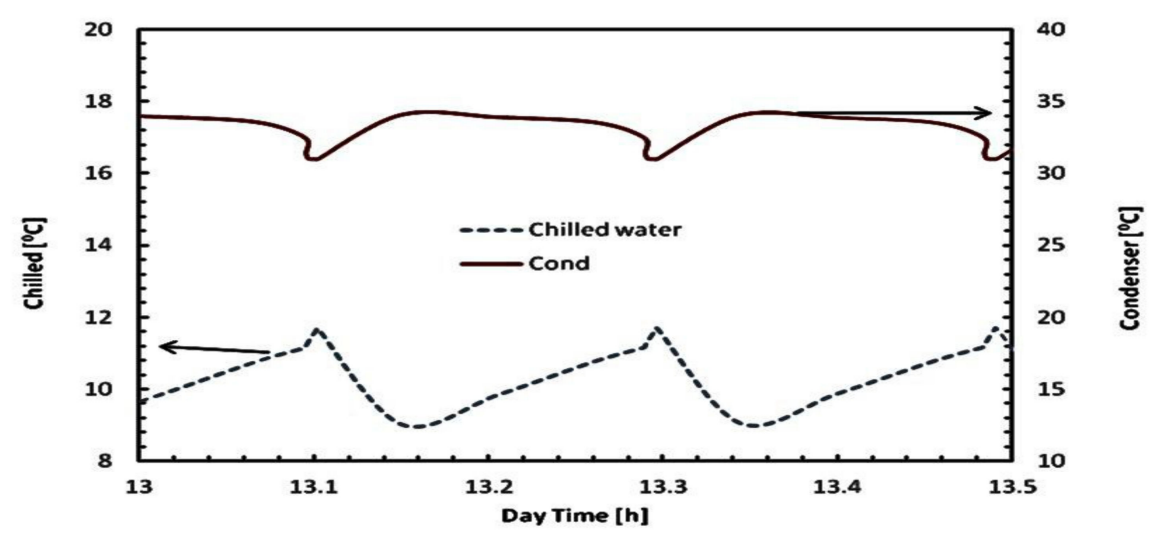

Figure 6. Water temperature at the outlets of both the condenser and evaporator.

\subsection{Performance Assessment}

Figure 7 shows the effect of the Fourier series order on the analytical evaluation of the cyclic average cooling capacity. As discussed in the radiation intensity section, the order of the Fourier series function did not have a significant effect on the cyclic cooling capacity. The average cooling capacity at peak time (13:00) was around $11.5 \mathrm{~kW}$. The average cooling capacity over the daytime from 9:00 to 17:00 was around $9.2 \mathrm{~kW}$ which is high enough to cool a residential building with $100-120 \mathrm{~m}^{2}$ floor area. Furthermore, high cooling capacity corresponds to high ambient temperature, which makes the solar adsorption chiller a perfect match to the cooling needs.

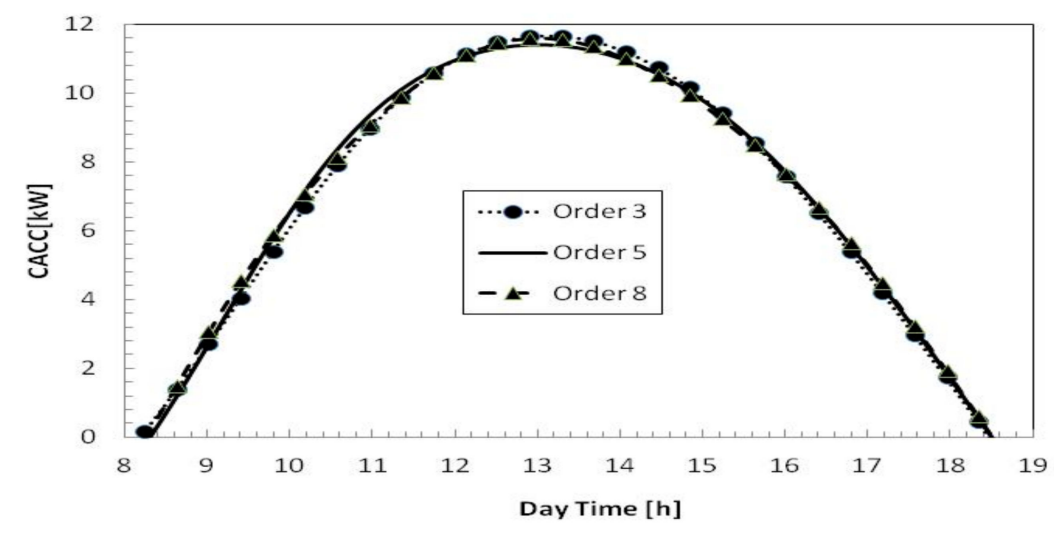

Figure 7. Cyclic average cooling capacity with a different order of Fourier series for Perth city. 
The average daily cycle, solar and net solar COPs of the proposed adsorption cooling system were evaluated based on 10 hours operation (between 8:00 and 18:00). Figure 8 shows the comparison between these three system COPs for a typical January day in Perth. The cycle and solar COPs increase as the time changes from 8:00 to 17:00 and 16:00, respectively. The net solar COPs achieve the maximum value at around 19:00 for a cycle time of $1500 \mathrm{~s}$ and a switching time of $30 \mathrm{~s}$. The solar adsorption system shows a relatively good cycle and solar COP. During the period 10:00 and 17:00, the system cycle COP ranges between 0.4 and 0.55 , and the solar COP ranges between 0.25 and 0.32 . The net system COP reaches 0.27 at 17:00. It also shows that high COPs occur in the afternoon. This is due to the high solar irradiation in the afternoon and the thermal inertia of heat exchangers and adsorbent/adsorbate materials inside the sorption beds. The partially cloudy weather conditions and low solar irradiation are the main reasons for the drop in the adsorption chiller performance. These trends of the cycle COP and solar COP agreed well with those reported in the literature [10]. As shown in Figure 7, for the time before 9:00 or after 18:00, the cooling capacity of the solar-adsorption cooling system is lower than 3 $\mathrm{kW}$ which is around $30 \%$ of the average cooling capacity for the period from 9:00 to 17:00. Therefore, only the analysis for the office hour is calculated.

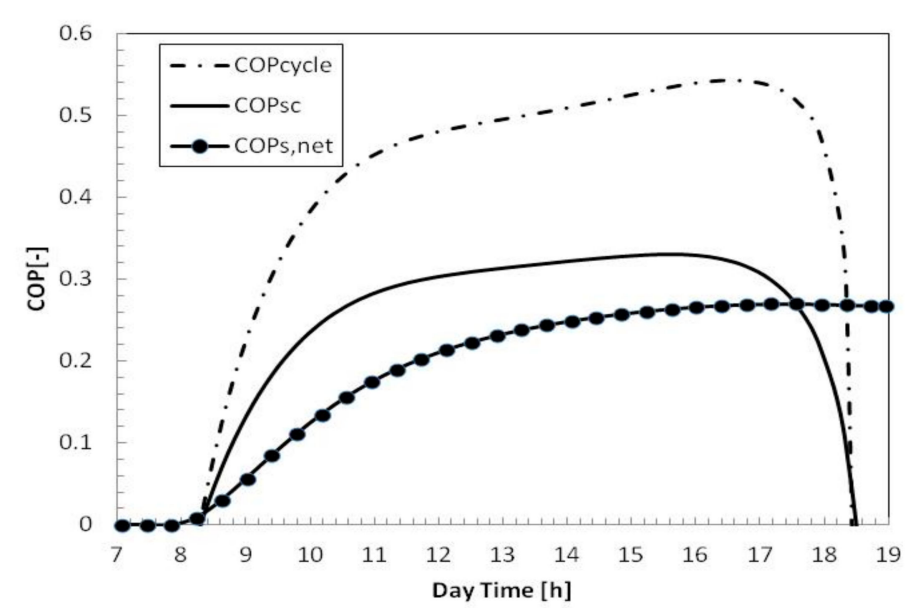

Figure 8. Variation of cycle coefficient of performance (COP), solar COP, and net solar COP for a typical day in January at Perth.

\subsection{Feasibility Studies}

Figure 9 shows the life cycle savings (LCS) of the solar thermal adsorption cooling system under different solar collector areas. The optimal collector area is found to be $38 \mathrm{~m}^{2}$, and life-cycle savings are around $\$ 3500$. The same conclusion is obtained from the Payback Period analysis as shown in Figure 9. Figure 10 presents the variation in the payback period of the solar adsorption cooling system. A collector area of $38 \mathrm{~m}^{2}$ yields the shortest payback period equal to 11 years. This 11-year payback period sounds not very appealing in terms of 20-year life span for a small residential building. However, if a large number of residential and commercial buildings were considered, this saving and environmental impact would make this technology very appealing for the community and country. These two figures demonstrate the promising potential for solar-adsorption cooling systems for climate conditions like Perth, Australia. 


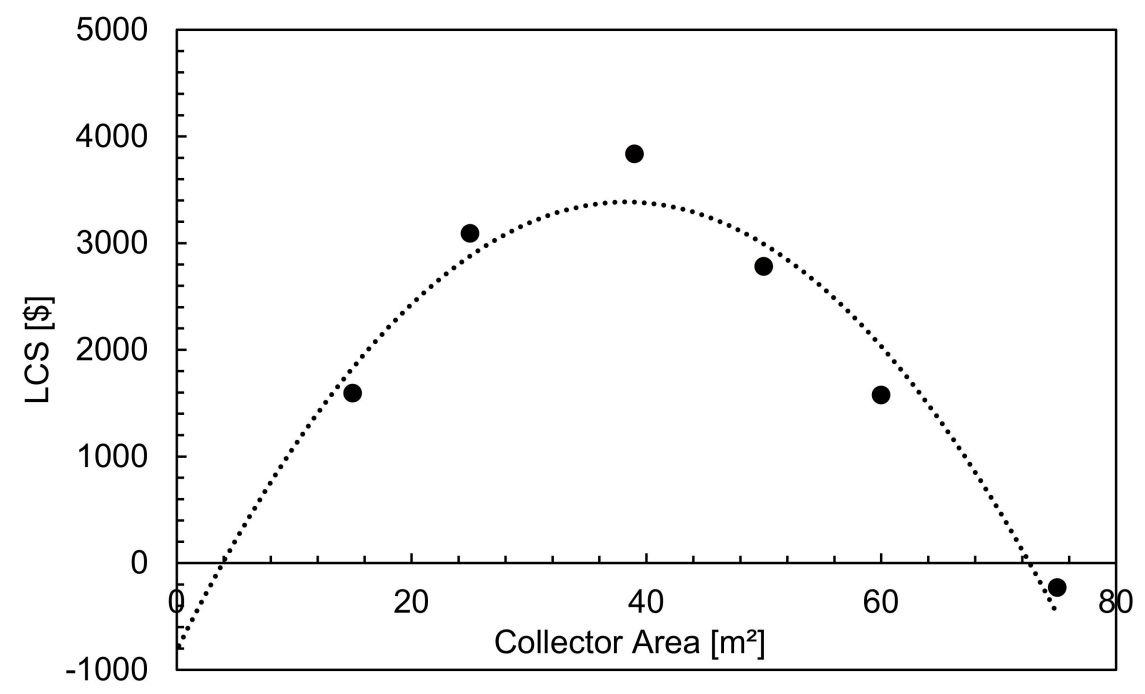

Figure 9. Life cost savings analysis for the solar-adsorption cooling system using different collector areas.

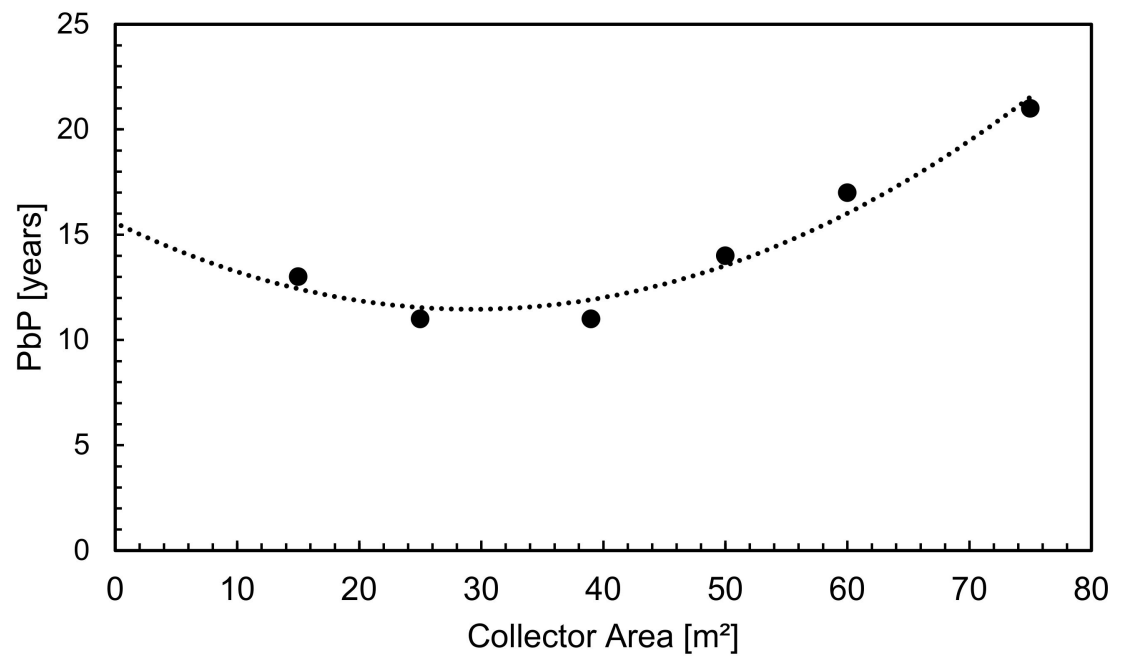

Figure 10. Payback period analysis for the solar-adsorption cooling system under different solar collector areas.

Figure 11 shows the impact of the unit cost of the solar collector on the life-cycle savings of the solar adsorption cooling system. It is found that the unit cost of the solar collector had a large impact on the life-cycle savings. As the solar collector unit price increases, the life-cycle savings reduce. If the unit cost of the collector was higher than $700 \$ . \mathrm{m}^{-2}$, the solar-adsorption cooling system becomes unfeasible for a system life span of 20 years.

Figure 12 shows the effect of interest rate on the LCS. The results showed that investment in the solar adsorption cooling system is feasible for a collector area of $38 \mathrm{~m}^{2}$ even if the interest rate is as high as $16 \%$. The results also show that the optimal collector area is around $38 \mathrm{~m}^{2}$ for all studied interest rates ranging from $4 \%$ to $16 \%$. This is consistent with the results shown in Figures 9 and 10. 


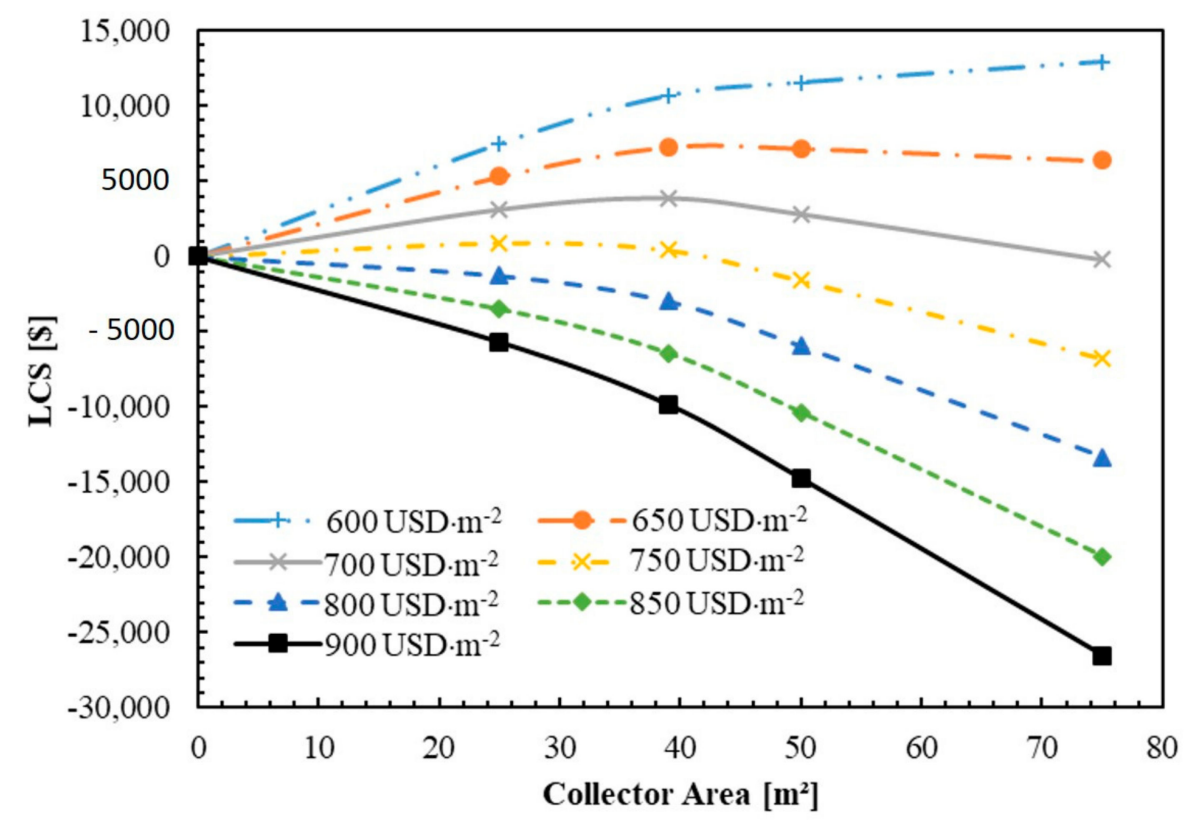

Figure 11. Effect of unit cost per $\mathrm{m}^{2}$ of the solar collector on the life-cycle saving.

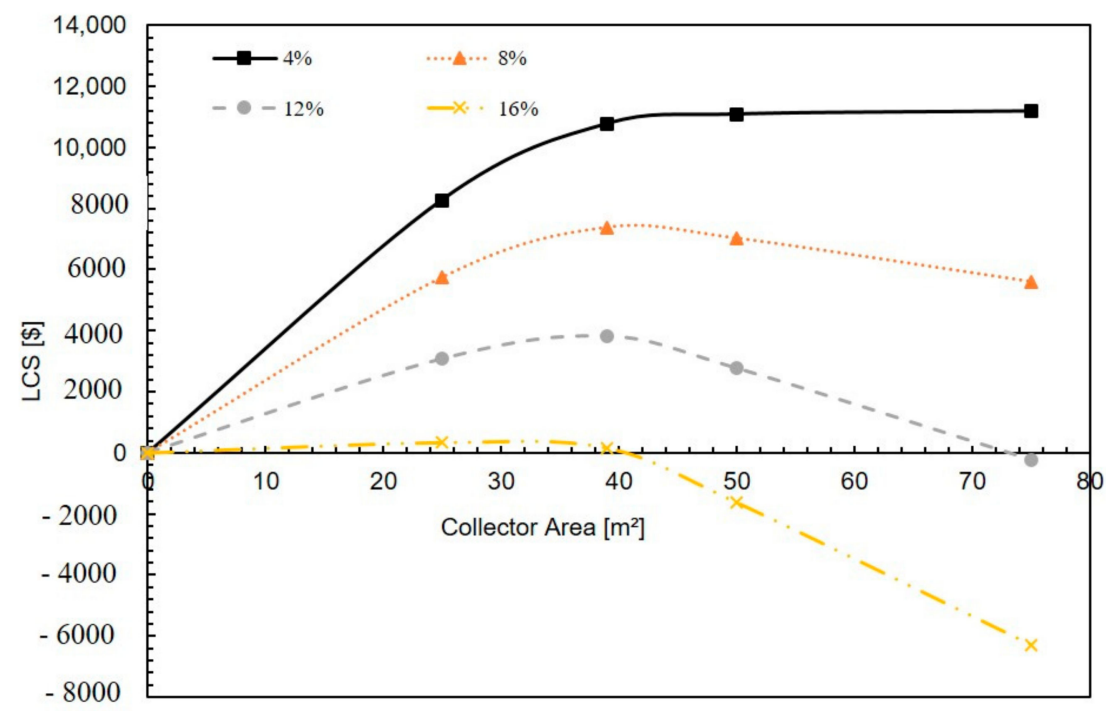

Figure 12. The effect of interest rate on the life-cycle saving at different collector area.

\section{Conclusions}

A dynamic and economic analysis of a solar thermally driven adsorption cooling system was performed under climatic conditions typical of Perth, Western Australia. The dynamics of this solar cooling system were first evaluated for a typical summer day, and then the Life-Cycle Savings and Payback Period economic methods were used to evaluate the feasibility of such cooling systems under different economic and operating conditions. Some useful conclusions were summarized below:

- The order of the Fourier series function did not have a strong impact on the simulation of the global radiation profile for performance evaluation of the solar cooling system

- The solar thermally driven adsorption chiller system showed a relatively good performance for the period between 10:00 and 17:00. During the period 10:00 and 17:00, the system cycle COP ranges between 0.4 and 0.55 , and the solar COP ranges between 0.25 and 0.32 . This indicated that solar adsorption cooling could provide effective cooling for residential or commercial buildings 
- Both life-cycle savings and payback period economic methods showed that the solar cooling system had an optimal solar collector area of $38 \mathrm{~m}^{2}$ in this study. For this collector area, the life-cycle savings were around $\$ 3500$ and the payback period was about 11 years for a residential building application. This demonstrated that solar-adsorption cooling has promising potential

- The solar cooling system was found to be feasible for a collector unit cost lower than $\$ 700$ per $\mathrm{m}^{2}$ and an interest rate of less than $16 \%$

Author Contributions: Conceptualization of the research work, X.W. and A.A.; design, theoretical framework and structure of the manuscript, results analyses, manuscript draft, A.A.; simulation works, K.C.A.A.; research work and finalizing the manuscript, X.W. All authors have read and agreed to the published version of the manuscript.

Funding: This research received no external funding.

Acknowledgments: The authors gratefully acknowledge the financial support provided by the Australian Endeavour scholarships and fellowships, Australian government.

Conflicts of Interest: The authors declare no conflict of interest.

\section{Nomenclature}

\begin{tabular}{|c|c|c|c|}
\hline A & area, $\mathrm{m}^{2}$ & PV & photovoltaic \\
\hline $\mathrm{ACF}$ & activated carbon fibre & $\mathrm{q}$ & adsorption capacity, $\mathrm{kg} \mathrm{kg}^{-1}$ \\
\hline$A_{c r}$ & each collector area, $\mathrm{m}^{2}$ & Qst & heat of adsorption, $\mathrm{J} \cdot \mathrm{kg}^{-1}$ \\
\hline C & $\begin{array}{l}\text { specific heat, } \mathrm{J} \cdot \mathrm{kg}^{-1} \cdot \mathrm{K}^{-1} ; \text { cost of installing solar } \\
\text { cooling equipment (USD) }\end{array}$ & $\mathrm{R}$ & gas constant, $\mathrm{J} \cdot \mathrm{kg}^{-1} \cdot \mathrm{K}^{-1}$ \\
\hline $\mathrm{C}_{\mathrm{A}}$ & $\begin{array}{l}\text { solar energy investment cost which is directly } \\
\text { proportional to the collector area }\end{array}$ & $\mathrm{Rp}$ & silica gel particle diameter, $\mathrm{m}$ \\
\hline CACC & cyclic average cooling capacity & SAR & solar-driven adsorption refrigeration \\
\hline CC & cooling capacity & SCP & specific cooling capacity \\
\hline$C_{\mathrm{E}}$ & $\begin{array}{l}\text { solar energy investment cost which is independent o } \\
\text { collector area }\end{array}$ & $\mathrm{T}$ & temperature, $\mathrm{K}$ \\
\hline $\mathrm{C}_{\mathrm{F}}$ & $\begin{array}{l}\text { the unit cost of delivered conventional energy for the } \\
\text { first year of analysis }\end{array}$ & $e_{t}$ & time, $\mathrm{s}$ \\
\hline COP & coefficient of performance & $\mathrm{U}$ & overall heat transfer coefficient, $\mathrm{W} \cdot \mathrm{m}^{-2} \cdot \mathrm{K}^{-1}$ \\
\hline $\mathrm{CPC}$ & compound parabolic concentrator & $\delta$ & flag functions \\
\hline CTAR & constant temperature adsorption refrigeration & Subscripts & \\
\hline Dso & diffusion coefficient, $\mathrm{m}^{2} \cdot \mathrm{s}^{-1}$ & am & ambient \\
\hline $\mathrm{E}$ & energy saving per year in USD & aux & auxiliary \\
\hline $\mathrm{Ea}$ & activation energy, $\mathrm{J} \cdot \mathrm{kg}^{-1}$ & bed & adsorbent bed \\
\hline ETC & evacuated tube solar collecting & chill & chilled water \\
\hline FPC & flat plate solar collector & cool & cool water \\
\hline $\mathrm{Ft}$ & total solar fraction of the solar system & con & condenser \\
\hline I & solar radiation, $\mathrm{W} \cdot \mathrm{m}^{-2}$ & eva & evaporator \\
\hline i & $\begin{array}{l}\text { the change in energy prices relative to general } \\
\text { inflation in the country, or energy inflation }\end{array}$ & 1 & liquid phase \\
\hline $\mathrm{L}$ & latent heat of vaporization, $\mathrm{J} \cdot \mathrm{kg}^{-1}$; total load & M & metal \\
\hline LCS & Life-Cycle Saving (\$) & $\mathrm{cr}$ & collector \\
\hline LMTD & $\log$ mean temperature difference, ${ }^{\circ} \mathrm{C}$ & hot & hot water \\
\hline M & mass, $\mathrm{kg}$ & in & inlet \\
\hline$\dot{m}$ & mass flow rate, $\mathrm{kg} \cdot \mathrm{s}^{-1}$ & $\mathrm{~s}$ & silica gel or saturation \\
\hline $\mathrm{n}$ & number of collectors & $\mathrm{r}$ & water \\
\hline NPV & net present value & out & outlet \\
\hline $\mathrm{OA}$ & optimal solar collector area $\left(\mathrm{m}^{2}\right)$ & $\mathrm{r}$ & refrigerant \\
\hline $\mathrm{P}_{1}$ & $\begin{array}{l}\text { the factor relating life cycle fuel cost to first-year fue } \\
\text { cost savings }\end{array}$ & ret & return \\
\hline $\mathrm{P}_{2}$ & $\begin{array}{l}\text { the factor relating life cycle by additional capital } \\
\text { investment to initial investment }\end{array}$ & SC & solar \\
\hline $\mathrm{PbP}$ & Payback Period (years) & $\mathrm{v}$ & vapour phase \\
\hline
\end{tabular}




\section{References}

1. Desideri, U.; Proietti, S.; Sdringola, P. Solar-powered cooling systems: Technical and economic analysis on industrial refrigeration and air-conditioning applications. Appl. Energy 2009, 86, 1376-1386. [CrossRef]

2. Hassan, H.Z.; Mohamad, A.A.; Alyousef, Y.; Al-Ansary, H.A. A review on the equations of state for the working pairs used in adsorption cooling systems. Renew. Sustain. Energy Rev. 2015, 45, 600-609. [CrossRef]

3. Al-Rbaihat, R.; Sakhrieh, A.; Al-Asfar, J.; Alahmer, A.; Ayadi, O.; Al-Salaymeh, A.; Al_hamamre, Z.; Al-bawwab, A.; Hamdan, M. Performance Assessment and Theoretical Simulation of Adsorption Refrigeration System Driven by Flat Plate Solar Collector. Jordan J. Mech. Ind. Eng. 2017, 11, 1-11.

4. El Fadar, A.; Mimet, A.; Pérez-García, M. Modelling and performance study of a continuous adsorption refrigeration system driven by parabolic trough solar collector. Sol. Energy 2009, 83, 850-861. [CrossRef]

5. Sah, R.P.; Choudhury, B.; Das, R.K. A review on adsorption cooling systems with silica gel and carbon as adsorbents. Renew. Sustain. Energy Rev. 2015, 45, 123-134. [CrossRef]

6. Ajib, S.; Alahmer, A. Solar Cooling Technologies. In Energy Conversion-Current Technologies and Future Trends; InTechOpen: London, UK, 2018.

7. Wang, X.; Chua, H.T.; Ng, K.C. Experimental investigation of silica gel-water adsorption chillers with and without a passive heat recovery scheme. Int. J. Refrig. 2005, 28, 756-765. [CrossRef]

8. Wang, X.; He, Z.; Chua, H.T. Performance simulation of multi-bed silica gel-water adsorption chillers. Int. J. Refrig. 2015, 52, 32-41. [CrossRef]

9. Alahmer, A.; Ajib, S.; Wang, X. Comprehensive strategies for performance improvement of adsorption air conditioning systems: A review. Renew. Sustain. Energy Rev. 2019, 99, 138-158. [CrossRef]

10. Wang, X.; Chua, H.T. Two bed silica gel-water adsorption chillers: An effectual lumped parameter model. Int. J. Refrig. 2007, 30, 1417-1426. [CrossRef]

11. Wang, X.; Chua, H.T. A comparative evaluation of two different heat recovery schemes as applied to a two-bed adsorption chiller. Int. J. Heat Mass Transf. 2007, 50, 433-443. [CrossRef]

12. Rezk, A.R.; Al-Dadah, R.K. Physical and operating conditions effects on silica gel-water adsorption chiller performance. Appl. Energy 2012, 89, 142-149. [CrossRef]

13. Deshmukh, H.; Maiya, M.P.; Murthy, S.S. Continuous vapour adsorption cooling system with three adsorber beds. Appl. Therm. Eng. 2015, 82, 380-389. [CrossRef]

14. Alsaqoor, S.; Alahmer, A.; Chorowski, M.; Pyrka, P.; Rogala, Z. Performance evaluation for a low-temperature heat powered for 3-beds with dual evaporators silica gel water adsorption chillers. In Proceedings of the 8th International Renewable Energy Congress (IREC), Amman, Jordan, 21-23 March 2017; pp. 1-6.

15. Chang, W.S.; Wang, C.C.; Shieh, C.C. Design and performance of a solar-powered heating and cooling system using silica gel-water adsorption chiller. Appl. Therm. Eng. 2009, 29, 2100-2105. [CrossRef]

16. Hassan, H.Z.; Mohamad, A.A.; Al-Ansary, H.A.; Alyousef, Y.M. Dynamic analysis of the CTAR (constant temperature adsorption refrigeration) cycle. Energy 2014, 77, 852-858. [CrossRef]

17. Hassan, H.Z.; Mohamad, A.A. Thermodynamic analysis and theoretical study of a continuous operation solar-powered adsorption refrigeration system. Energy 2013, 61, 167-178. [CrossRef]

18. Habib, K.; Saha, B.B.; Koyama, S. Study of various adsorbent-refrigerant pairs for the application of solar driven adsorption cooling in tropical climates. Appl. Therm. Eng. 2014, 72, 266-274. [CrossRef]

19. Habib, K.; Choudhury, B.; Chatterjee, P.K.; Saha, B.B. Study on a solar heat driven dual-mode adsorption chiller. Energy 2013, 63, 133-141. [CrossRef]

20. Zhai, X.Q.; Wang, R.Z.; Wu, J.Y.; Dai, Y.J.; Ma, Q. Design and performance of a solar-powered air-conditioning system in a green building. Appl. Energy 2008, 85, 297-311. [CrossRef]

21. Sumathy, K.; Yong, L.; Muller Steinhagen, H.; Kerskes, H. Performance analysis of a modified two-bed solar-adsorption air-conditioning system. Int. J. Energy Res. 2009, 33, 675-686. [CrossRef]

22. Tsoutsos, T.; Anagnostou, J.; Pritchard, C.; Karagiorgas, M.; Agoris, D. Solar cooling technologies in Greece. An economic viability analysis. Appl. Therm. Eng. 2003, 23, 1427-1439. [CrossRef]

23. Al-Ugla, A.A.; El-Shaarawi, M.A.; Said, S.A.; Al-Qutub, A.M. Techno-economic analysis of solar-assisted air-conditioning systems for commercial buildings in Saudi Arabia. Renew. Sustain. Energy Rev. 2016, 54, 1301-1310. [CrossRef]

24. Alahmer, A.; Wang, X.; Al-Rbaihat, R.; Alam, K.A.; Saha, B.B. Performance evaluation of a solar adsorption chiller under different climatic conditions. Appl. Energy 2016, 175, 293-304. [CrossRef] 
25. Carr, A.J.; Pryor, T.L. A comparison of the performance of different PV module types in temperate climates. Sol. Energy 2004, 76, 285-294. [CrossRef]

26. Alam, K.A.; Saha, B.B.; Akisawa, A. Adsorption cooling driven by solar collector: A case study for Tokyo solar data. Appl. Therm. Eng. 2013, 50, 1603-1609. [CrossRef]

27. Jaiswal, A.K.; Mitra, S.; Dutta, P.; Srinivasan, K.; Murthy, S.S. Influence of cycle time and collector area on solar driven adsorption chillers. Sol. Energy 2016, 136, 450-459. [CrossRef]

28. Clausse, M.; Alam, K.C.; Meunier, F. Residential air conditioning and heating by means of enhanced solar collectors coupled to an adsorption system. Sol. Energy 2008, 82, 885-892. [CrossRef]

29. Sayfikar, M.; Behbahani-nia, A. Study of the performance of a solar adsorption cooling System. Energy Equip. Syst. 2013, 1, 75-90.

30. Ghoneim, A.A.; Abdullah, A.H. Feasibility Study of Solar Heating and Cooling Systems in Kuwait. Destin. Renew. ANZSES 2003, 239-248.

31. Duffie, J.A.; Beckman, W.A. Solar Engineering of Thermal Process, 4th ed.; Wiley Interscience: New York, NY, USA, 2013.

32. Wang, X.; Bierwirth, A.; Christ, A.; Whittaker, P.; Regenauer-Lieb, K.; Chua, H.T. Application of geothermal absorption air-conditioning system: A case study. Appl. Therm. Eng. 2013, 50, 71-80. [CrossRef]

33. Lu, Z.S.; Wang, R.Z. Experimental performance investigation of small solar air-conditioning systems with different kinds of collectors and chillers. Sol. Energy 2014, 110, 7-14. [CrossRef]

34. Al-Alili, A.; Hwang, Y.; Radermacher, R.; Kubo, I. Optimization of a solar powered absorption cycle under Abu Dhabi's weather conditions. Sol. Energy 2010, 84, 2034-2040. [CrossRef]

35. Gebreslassie, B.H.; Guillén-Gosálbez, G.; Jiménez, L.; Boer, D. Design of environmentally conscious absorption cooling systems via multi-objective optimization and life cycle assessment. Appl. Energy 2009, 86, 1712-1722. [CrossRef]

36. Chang, W.S.; Wang, C.C.; Shieh, C.C. Experimental study of a solid adsorption cooling system using flat-tube heat exchangers as adsorption bed. Appl. Therm. Eng. 2007, 27, 2195-2199. [CrossRef]

(C) 2020 by the authors. Licensee MDPI, Basel, Switzerland. This article is an open access article distributed under the terms and conditions of the Creative Commons Attribution (CC BY) license (http://creativecommons.org/licenses/by/4.0/). 